\title{
原著
}

\section{Expression of tumor markers in uterine sarcoma: Immunocytochemical study}

\author{
Department of Obstetrics and Gynecology, Public Kakunodate Hospital ${ }^{1)}$, Clinical Laboratory, \\ Ogachi Central Hospital ${ }^{2)}$, Department of Pathology, Akita Red Cross Hospital ${ }^{3)}$ \\ Shinichi Igarashi ${ }^{1)}$, Keiji Naito ${ }^{2)}$, Shigeo Sato ${ }^{2)}$ \\ Koichi $\mathrm{Nara}^{3)}$, Sadahiro Hosobe ${ }^{3)}$
}

\begin{abstract}
Expression of the tumor markers in uterine sarcomas was investigated using immunocytochemistry. We found that several tumor markers were expressed heterogeneously in uterine sarcomas as well as in the epithelial tumors. Carcinoembryonic antigen, $\alpha$-fetoprotein, NCC$\mathrm{CO} 450$, epithelial membrane antigen and sialyl Tn were expressed in uterine sarcomas significantly higher than controls.

Understanding of the tumor markers in uterine sarcoma may contribute to the detection of the disease at early stage. Immunocytochemistry of tumor markers as functional molecules may be very useful to understand biological behavior of uterine sarcoma.
\end{abstract}

Key words : Uterine sarcoma-Immunocytochemistry_-Tumor marker

\section{Introduction}

Uterine sarcoma is a rare tumor, which may tend to understand the tumor character insufficiently. Detection of uterine sarcoma at early stage is difficult, and the remedy adequate for the disease is not fully established, which may lead the patients to poor prognosis. To solve such problems,

Expression of tumor markers in uterine sarcoma: Immunocytochemical study

Shinichi IGARASHI ${ }^{11}$, M.D., Keiji NAITO ${ }^{2)}$, C.T., J.S.C., Shigeo SATO ${ }^{2)}$, C.T., J.S.C., Koichi NARA ${ }^{3)}$, C.T., I.A.C., Sadahiro HOSOBE ${ }^{3)}$, C.T., I.A.C.

${ }^{1)}$ Department of Obstetrics and Gynecology, Public Kakunodate Hospital, ${ }^{2)} \mathrm{Clinical}$ Laboratory, Ogachi Central Hospital, ${ }^{3}$ Department of Pathology, Akita Red Cross Hospital

論文別刷請求先 严014-03 秋田県仙北郡角館町岩瀬字上野 18 公立角館病院産婦人科 五十嵐信一

平成 5 年 11 月 12 日受付

平成 6 年 2 月 18 日受理 cytological and immunocytochemical approaches may be beneficial because it has wide information about morphological and chemical character of the tumor ${ }^{1)}$.

Recent progresses in tumor markers are remarkable. Tumor markers have been essential in cancer detection and/or the treatment. However, most of the tumor markers were found against epithelial tumors as immunogens, while the significance of tumor markers in nonepithelial tumors is not fully discussed ${ }^{2,3}$. In the present study, we investigated the significance of tumor markers in uterine sarcoma immunocytochemically.

\section{Materials and Methods}

Tumors were obtained immediately after excision from patients undergoing routine surgery. The materials from 24 patients with uterine sarcoma and 
10 patients with uterine leiomyoma as the controls were obtained and studied retrospectively. Several malignant tumors were included in the study group as follows: 11 endometrial stromal sarcomas, 9 leiomyosarcomas, 3 rhabdomyosarcomas (pleomorphic type) and an osteosarcoma. Study group in cluded 4 mixed Müllerian tumors. However, we used smears from clearly sarcomatous parts, which were histologically defined. In the control group, smears were obtained from myometrium of the uterine leiomyoma, because we thought that the differential diagnosis between uterine sarcoma and leiomyoma was critical problem clinically. Touch smears from the tumors were fixed in $95 \%$ alcohol and stained with Papanicolaou and immunocytochemical techniques. In the same part of tumor, histological and immunohistochemical examina- tions from formalin-fixed tissue sections were performed.

Antibodies raised against the following antigens was used (Table 1): Carcinoembryonic antigen ${ }^{4)}$ (CEA, Dako Co., Santa Barbara, CA, USA) ; $\alpha$ fetoprotein $^{5)}$ (AFP, Nichiray Co., Tokyo, Japan); basic fetoprotein ${ }^{6}$ (BFP, Nihonkayaku Co., Tokyo, Japan) ; CA 125 $\quad$ (Dako Co.) ; CA 19-98) (Dako Co.) ; CA 72-4 ${ }^{9)}$ (Toray Fuji Bionics Co., Tokyo, Japan) ; NCC-CO 45010) (Nihonkayaku Co., Tokyo, Japan) ; NCC - ST 43911) (Nihonkayaku Co.) ; epithelial membrane antigen ${ }^{12)}$ (EMA, Dako Co.) and sialyl $\mathrm{Tn}^{13)}$ (STN, Otsuka Assay Inst., Tokushima, Japan). All antibodies were diluted in phosphate-buffered saline ( $\mathrm{pH} 7.4$ ) with $1 \%$ bovine serum albumin. The antigen-antibody reaction was then visualized employing the avidin biotin

Table 1 Properties and immunogens of the tumor markers

\begin{tabular}{|c|c|c|c|}
\hline Tumor marker & Antibody & Property & Immunogen \\
\hline CEA & A 5 B 7 & $\begin{array}{l}\text { glycoprotein } \\
\text { M.W. } 180 \text { kDa E.M. } \beta \\
\text { carbohydrate } 40-60 \% \\
\text { oncofetal antigen }\end{array}$ & fetal intestine \\
\hline $\mathrm{AFP}$ & 292161 & $\begin{array}{l}\text { glycoprotein } \\
\text { M.W. } 38 \mathrm{kDa} \text { E.M. } \alpha_{1} \\
\text { carbohydrate } 4 \% \\
\text { oncofetal antigen }\end{array}$ & hepatoma \\
\hline $\mathrm{BFP}$ & $\mathrm{K}-1$ & $\begin{array}{l}\text { protein } \\
\text { M.W. } 55 \mathrm{kDa} \text { E.M. } \gamma \\
\text { pI }=9.3 \\
\text { oncofetal antigen }\end{array}$ & fetal serum, colon, brain \\
\hline CA 125 & OC 125 & $\begin{array}{l}\text { glycoprotein } \\
\text { M.W. } 550 \mathrm{kDa}\end{array}$ & ovarian carcinoma \\
\hline CA $19-9$ & NS $19-9$ & $\begin{array}{l}\text { glycolipid M.W. } 36 \mathrm{kDa} \\
\text { monosialoganglioside }\end{array}$ & colon carcinoma \\
\hline CA $72-4$ & B 72.3 & $\begin{array}{l}\text { glycoprotein } \\
\text { M.W. } 1000 \mathrm{kDa} \\
\text { sialyl-sugar residue }+\end{array}$ & breast carcinoma \\
\hline NCC-CO 450 & NCC-CO 450 & $\begin{array}{l}\text { glycoprotein } \\
\text { M.W. }>400 \mathrm{kDa} \\
\text { no sialic acid } \\
\text { mucinous type sugar chain }+\end{array}$ & colon carcinoma \\
\hline NCC-ST 439 & NCC-ST 439 & $\begin{array}{l}\text { glycoprotein } \\
\text { M.W. }>1000 \mathrm{kDa} \\
\text { sialyl-sugar residue }+\end{array}$ & gastric carcinoma \\
\hline EMA & E 29 & $\begin{array}{l}\text { glycoprotein } \\
\text { M.W. } 3000 \mathrm{kDa}\end{array}$ & milk fat globule \\
\hline STN & TKH -2 & $\begin{array}{l}\text { glycoprotein } \\
\text { M.W. }>1000 \mathrm{kDa} \\
\text { sialyl-sugar residue }+ \\
\text { onco-developmental antigen }^{-}\end{array}$ & sheep mandibular gland \\
\hline
\end{tabular}

M.W. : molecular weight

E.M. : electrophoretic mobility (globulin region) 
Table 2 Incidence of expression of tumor markers in uterine sarcoma

\begin{tabular}{llcccccc}
\hline \hline Tumor Marker & ESS & LMS & RMS & OS & Total & Control & p value \\
\hline CEA & $5 / 9$ & $2 / 8$ & $1 / 3$ & $0 / 1$ & $8 / 21(38.1)$ & $1 / 10$ & $<0.03$ \\
AFP & $4 / 9$ & $2 / 8$ & $2 / 3$ & $1 / 1$ & $9 / 21(42.9)$ & $1 / 10$ & $<0.02$ \\
BFP & $4 / 10$ & $1 / 9$ & $2 / 3$ & $0 / 1$ & $7 / 23(30.4)$ & $1 / 10$ & n.s. \\
CA 125 & $1 / 10$ & $1 / 9$ & $0 / 2$ & $0 / 1$ & $2 / 22(9.1)$ & $1 / 10$ & n.s. \\
CA 19-9 & $1 / 8$ & $1 / 8$ & $0 / 2$ & $0 / 1$ & $2 / 19(10.5)$ & $1 / 10$ & n.s. \\
CA 72-4 & $5 / 10$ & $2 / 8$ & $1 / 3$ & $1 / 1$ & $9 / 22(40.9)$ & $1 / 10$ & $<0.02$ \\
NCC-CO 450 & $7 / 10$ & $3 / 8$ & $2 / 3$ & $1 / 1$ & $13 / 22(59.1)$ & $1 / 10$ & $<0.01$ \\
NCC-ST 439 & $2 / 11$ & $2 / 8$ & $2 / 3$ & $0 / 1$ & $6 / 23(26.1)$ & $1 / 10$ & n.s. \\
EMA & $5 / 10$ & $4 / 7$ & $1 / 1$ & $0 / 1$ & $10 / 19(52.6)$ & $1 / 10$ & $<0.01$ \\
STN & $2 / 7$ & $1 / 4$ & $2 / 2$ & $0 / 1$ & $5 / 14(35.7)$ & $1 / 10$ & $<0.05$ \\
\hline
\end{tabular}

Each value was compared to that in the control group. Figures in parentheses indicate percentage.

ESS : endometrial stromal sarcoma, LMS : leiomyosarcoma, RMS : rhabdomyosarcoma, OS : osteosarcoma, n.s. : not significant

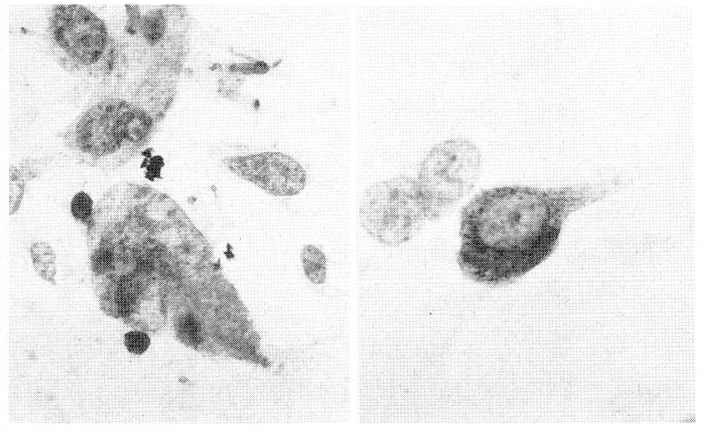

Fig. 1 Diffuse cytoplasmic reactivities were found in leiomyosarcoma cell against NCC-CO 450 (left) and in rhabdomyosarcoma cell against $\mathrm{CA} 72-$ 4 (right). (ABC method, $\times 40)$

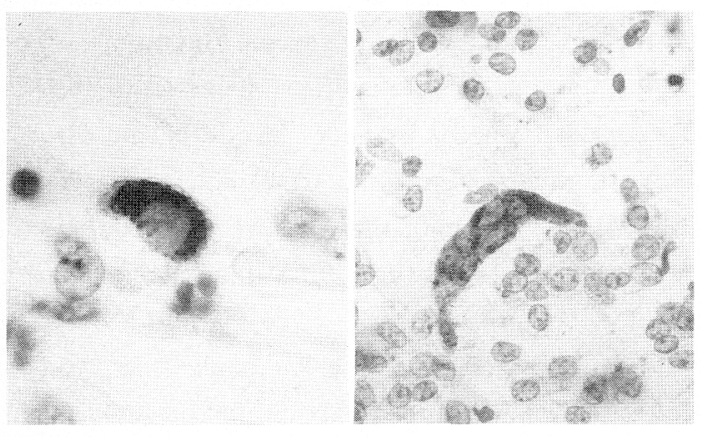

Fig. 3 Granular cytoplasmic reactivities were found in endometrial stromal sarcoma cell against CEA (left) and in leiomyosarcoma cell against AFP (right). (ABC method, $\times 40)$

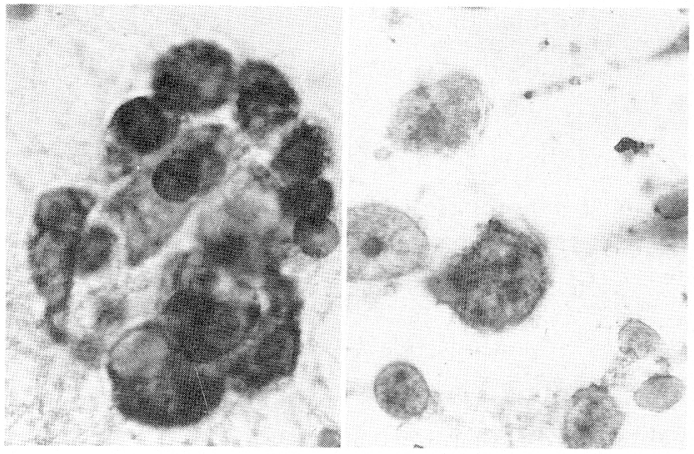

Fig. 2 Marginal reactivities were found in endometrial stromal sarcoma cell against EMA (left) and in rhabdomyosarcoma cell against STN (right). $(\mathrm{ABC}$ method, $\times 40)$

complex (ABC) method using a kit (Vectastain ; Mountain View, CA, USA), and diaminobenzidine as chromogen. A sample of appropriate positive controls, cytological materials of ovarian carcinoma were stained in a parallel fashion with the tumor tissues. Negative controls, substituting nonimmune mouse serum samples for the primary antibody, were used to assess quality of the immunoperoxidase staining.

Evaluation of the staining was conducted by two independent investigators, and subsequent diagnosis was reviewed by a panel that included the authors. Staining was judged as positive if the frequency of positive cells was $>25 \%$ in cytology as well as in histology. The incidence of positive patients in 
each tumor marker was compared with the controls by Fisher's exact test.

\section{Results}

The incidence of positive cases in tumor markers is shown in Table 2 . No reactive staining against the studied tumor markers was observed either in cytologically defined endometrial stromal cells or in muscle cells in leiomyomas. The expression of CEA, AFP, CA 72-4, NCC-CO 450, EMA or STN in uterine sarcomas was higher than in the controls. However, the expression of BFP, CA 125, CA 19-9 or NCC-ST 439 showed no significant increase. Strong cytoplasmic reactivity against NCC-CO 450 in the endometrial stromal sarcoma cells was detected. No reactivity against CA 125 or CA 19-9 was found in rhabdomyosarcoma cells. In the immunohistochemical analysis done in parallel, similar pattern was seen.

Various staining patterns were observed against several tumor markers. Diffuse cytoplasmic (Fig. 1) or marginal reactivity (Fig. 2) in tumor cells, or granular cytoplasmic reactivity (Fig. 3) was found.

\section{Discussion}

Recent progress in tumor markers has been contributing in cancer detection and treatment. The tumor markers are classified into onco-fetal (developmental) antigens, cancer associated antigens, hormones, isoenzymes and the others. Most of the cancer associated antigens are glycoproteins. Several tumor marker proteins have been clarified to have important functions in oncogenesis, cell differentiation, cell adhesion and immunological recognition. However, most of the tumor markers were found against epithelial tumors as immunogens, while the significance of tumor markers in nonepithelial tumors is not fully discussed $^{2,3)}$. Miettinen et al. ${ }^{14)}$ have discovered epithelial markers in sarcoma. Mills et al. ${ }^{15)}$ noted no EMA or keratin positivity in leiomyosarcomas from various organs. We found that the tumor markers including EMA are expressed in nonepithelial tumors as well as in epithelial tumors.

In the process of oncogenesis lacking differentiation in uterine sarcoma, gene mutations may lead expression not only of oncogene products but also of epithelial tumor markers. Some of the sarcomas may have potentiality to make epithelial tumors. Analysis of expression of tumor markers may provide new knowledge of uterine sarcoma.

Tumor microenvironment may affect the nature of sarcoma as well as carcinoma. Chung ${ }^{16)}$ reported that microenvironmental factors may have an influence on the regulation of genes of molecular markers. A certain microenvironmental factor may induce change in the nature of the neoplastic cells, resulting in the appearance of positivity against tumor markers. In the metastatic process of the malignant tumors, it is very interesting to know whether tumor marker antigens have a role in tumor behavior. Some of the antigens may have function as adhesion molecules.

Within the limits of neoplasm, a new panel of tumor markers for differentiation epithelial elements from nonepithelial elements is required ${ }^{17)}$. Further, new combination of tumor markers useful in uterine sarcoma is necessary, especially for detection at early stage and of the recurrence. Indeed, tumor markers in sera were decreased by hysterectomy in a few evaluable cases. But many cases had no positive serum marker. A heterogeneity in expression of tumor markers is a very important, but difficult problem in the treatment.

In conclusion, tumor markers were expressed not only in the epithelial tumors but also in the uterine sarcomas heterogeneously. Understanding of the tumor markers as functional molecules can contrib. ute to detection of uterine sarcomas at early stage and to know the biological behavior.

\section{要 約}

免疫細胞化学を用い, 子宮肉腫における腫瘍マーカーの発現 を検討した，多くの腫瘍マーカーは，上皮性腫瘍同様に，子宮 肉腫でも不均一ながら発現がみられた. Carcinoembryonic 
antigen, $\alpha$-fetoprotein, NCC-CO 450, epithelial membrane antigen, sialyl Tnが良性コントロールに比し, 子宮肉腫で有 意に高頻度に発現していた。

子宮肉腫における腫瘍マーカーに関して多くの情報が得られ れば，早期発見や治療に有用と思われる.また機能分子として の腫瘍マーカーに関する, 免疫細胞化学的検討は, 子宮肉腫の 生物学的動態の把握に有力な武器となると思われる.

\section{References}

1) Flens, M.J., Valk, P., Tadema, T.M., et al. : The contribution of immunocytochemistry in diagnostic cytology, Comparison and evaluation with immunohistology, Cancer, 65:2704 2711, 1990.

2) Dabbs, D.J., Silvermann, J.F., Geisinger, K.R. : Immunohistochemical study of uterine stromal sarcoma and rhabdomyosarcoma, Arch. Pathol. Lab. Med., $113:$ 1151 1154, 1989.

3) Fisher, C.: The value of electronmicroscopy and immunohistochemistry in the diagnosis of soft tissue sarcomas: a study of 200 cases, Histopathology, $16: 441 \sim 454,1990$.

4) Gold, P., Freedman, S.O. : Demonstration of tumorspecific antigens in human colonic carcinoma by immunological tolerance and absorption techniques. J. Exp. Med., 121 : 439, 1965.

5) Abelev, G.I., Perova, S., Khramkowa, N. : Production of embryonal $\alpha$-globulin by transplantable hepatomas. Transplantation, $1: 174,1963$.

6) Ishii, M. : A new carcinoembryonic protein characterized by basic property. Scand. J. Immunol., 8(suppl. 8) : 611, 1978.

7) Bast, R.C.Jr., Feeney, M., Lazarus, H., et al. : Reactivity of a monoclonal antibody with human ovarian carcinoma. J. Clin. Invest., $68: 1331,1981$.

8) Koprowski, H., Steplewski, Z., Mitchell, K. : Colo- rectal carcinoma antigens detected by hybridoma antibodies. Somatic Cell Genet., 5: 952, 1979.

9) Colcher, D., Hand, P.H., Nuti, M., et al. : A spectrum of monoclonal antibodies reactive with human mammary tumor cells. Proc. Natl. Acad. Sci. USA, 78 : 3199 3203, 1981.

10) Sakurai, Y., Hirohashi, S., Shimosato, Y., et al. : Selection of monoclonal antibody reactive with highmolecular-weight glycoprotein circulating in the body fluid of gastrointestinal cancer patients. Cancer Res., 48 : 4053 4058, 1988.

11) Hirohashi, S., Watanabe, M., Shimosato, Y., et al. : A monoclonal antibody reactive with the siayl-sugar residue of a high molecular glycoprotein in sera of cancer patients, Gann, 75 : 485 488, 1984.

12) Ormerod, M.G., Steele, K., Westgood, J.H., et al. : Epithelial membrane antigen: Partial purification assay and properties. Br. J. Cancer, 48: 533 541, 1983.

13) Kjeldsen, T., Clausen, H., Hirohashi, S., et al. : Preparation and characterization of monoclonal antibodies directed to the tumor-associated o-linked sialosyl-2$6 \alpha$-N-acetylgalactosaminyl (sialosyl-Tn). Cancer Res., $48: 2211 \sim 2220,1988$.

14) Miettinen, M. : Immunoreactivity for cytokeratin and epithelial membrane antigen in leiomyosarcoma, Arch. Pathol. Lab. Med., 112 : 637 640, 1988.

15) Mills, S.E., Bova, S., Young, R.H. : Leiomyosarcoma of the urinary bladder, Am. J. Surg. Pathol., 13:480 〜 489, 1989.

16) Chung, M.T., Mukai, K., Teshima, S., et al. : Expression of various antigens by different component of uterine mixed Müllerian tumors. An immunohistochemical study, Acta. Pathol. Jpn., $33:$ 35 45, 1988.

17) Ridley, P.D., Braimbridge, M.V. : Primary sarcoma of the lung : potential dangers of immunocytochemistry, Br. J. Clin. Pract., $44: 685 \sim 688,1990$. 